\title{
Challenges in geospatial documentation of unprotected built heritage sites in India
}

\author{
Kuili Suganya* \\ India is generally accepted as a treasure trove of many thousands of built heritage sites. If one \\ looks for a list of such sites with its geographical location and some basic identificatory descrip- \\ tion, unfortunately there is none, except for the ones protected by the Government authorities. \\ Today with most geospatial databases being on digital platform, it is extremely important to recog- \\ nize and also include the unprotected built heritage sites. Doing this is the need for the hour, in \\ light of dramatic changes to the landscape caused by developmental activities that are insensitive \\ to cultural heritage. This article looks in detail at the extent of digital information available on the \\ location of Indian monuments (both protected and unprotected), the challenges in extracting and \\ bringing it into a geospatial platform with the case study of Arasibidi in north Karnataka, India.
}

Keywords: Arasibidi, digital heritage, geospatial documentation, listing unprotected monuments.

Given India's rich architectural heritage, even with best efforts using traditional documentation methods, a complete list of all the ancient monuments (any man-made structure which has 'historical, archaeological and artistic interest' that has been in existence for more than a hundred years as defined by Ancient Monuments Act of India $^{1}$ ) has not been created. At present, the Archaeological Survey of India (ASI) looks after more than 3600 ancient monuments of national importance, and the Department of Archaeology of each state typically takes care of a few hundred more. Many of the living temples and other places of worship are managed by the endowment department of respective states; in Karnataka, there are about 34,543 such temples ${ }^{2}$. Even so, there are thousands of monuments that remain undocumented, unprotected and their existence has gone unnoticed especially when they are not in use or under litigation. The increase in developmental activities and mechanized means available now for flattening land and building has caused irreparable damage to these monuments and many have been effaced even before they have been recognized and documented. In this scenario, geospatial documentation is a swift method to record sites before losing them.

Geospatial documentation here is different from the geocoding/toponyms resolution which uses 'machinelearned classifiers ${ }^{3}$ to assign geo-coordinates to placenames from a digital archival database ${ }^{4}$. The documentation discussed in the present article is not a data entry task where the list is already available in literature/records or with government listing that can be fed in-

Kuili Suganya is in the National Institute of Advanced Studies, IISc Campus, Bengaluru, 560012, India and also in the Manipal Academy for Higher Education, Manipal 576 104, India.

*e-mail: kuilisuganya@gmail.com to the digital domain. The kind of compilation discussed here is a prerequisite for creating an effective digital archival database of location of heritage sites. Creating such database requires authentic identification of the precise geo-coordinates of the heritage sites by meticulous scrutiny of literature followed by systematic ground validation. This narrative uses the identification of two such monuments and other neighbouring ruins as an example. These monuments are located in an uninhabited settlement called Arasibidi (a Western Chalukyan capital, active between the 11 th and 12th century) in the Bagalkot district, Karnataka ${ }^{5,6}$. In spite of this settlement having three inscriptions protected by ASI, it was a challenge to identify the settlement and its ruins.

Geospatial documentation of the monuments involves the process of first identifying the location of the settlement and then listing the various monuments in it. This way, one would tag geographical coordinates to the ancient monuments along with the name of the settlement to form a geospatial vector layer file which is a primary data layer for the geospatial platform ${ }^{7}$. Such a recording plays a vital role in bringing these historically important monuments onto the geospatial platform for spatial visualization. Such visualization helps in delineation of heritage zones during planning for infrastructure developmental activities by various governmental and non-governmental bodies, and also in creating awareness about the heritage in the local community ${ }^{8}$.

\section{History of the documentation of built heritage in India}

The beginning of documentation of monuments in India can be traced to hand-drawn paintings made in the 
late-eighteenth century. Subsequently, architectural documentation began in the mid-nineteenth century through drawings and reports 9 . With establishment of ASI and interest from the then British administration - official governmental surveying and listing of all the monuments of India began ${ }^{10}$ in 1861 and the list was published ${ }^{11}$ in 1870. By 1885, ASI of Western India had compiled an exhaustive list of monuments spread across 953 settlements in Bombay Presidency ${ }^{12}$ alone. The enactment of ancient monuments preservation acts 1904 (ref. 13), 1951 (ref. 14) and 1956 (ref. 1), led to ASI taking custody of a selected few monuments ${ }^{15}$. Out of more than 3600 monuments protected by ASI today, 747 (ref. 16) are in Karnataka. Apart from these, the Directorate of Archaeology, Museums and Heritage ${ }^{17}$ (DAMH), Government of Karnataka, protects 753 monuments. According to the central audit report, a complete list of ASI protected monuments, with the accurate location was not available until 2013 (ref. 15). Presently the geographical coordinates of all the monuments protected by ASI are available in the public domain ${ }^{18}$. Today apart from the monuments which are under the government's protection, the rest of the thousands of monuments are either as living heritage undergoing rapid change to its original architecture through unsympathetic interventions ${ }^{19}$ or lost to infrastructure works or in ruinous state ${ }^{20}$. The Indian heritage charter ${ }^{19}$ states that the weakness of the current list of the protected monuments in India is the absence of a list of unprotected monuments and heritage settlements.

For authentic geospatial documentation, one needs to first compile a list of all sites and then geotag them by finding their geographical location. Their geographical location may be recorded either in old maps ${ }^{21}$ or in published literature (gazetteer, inscriptions and antiquarian reports ${ }^{19}$ ) which would have a description along with information about their geographical coordinates or information of administrative region (Presidency/State/ district/sub-district) they fall in, or direction to reach them from nearby towns. Most such references lack accuracy and pose difficulties in identifying their exact location (especially with formation and transformation of administration boundaries). The following section discusses various kinds of data available on the location of the settlement of Arasibidi, the challenges they posed and the process in which their accurate geo-coordinates were finally identified.

\section{Geotagging Arasibidi}

The settlement of Arasibidi was listed in one of the first antiquarian reports of the Bombay Presidency in 1877 (ref. 22) as an ancient Chalukyan capital (Vikramapura being its ancient name) with two ruinous temples, two inscriptions and an ancient tank. Arasibidi was one among seven settlements listed in Hungund taluk (sub-district) of
Kaladgi zilla (district), the others being Aihole, Hungund, Sangama, Karadi, Nandwadige and Kelur. A search in Google search engine, its maps and BHUVAN (an Indian geo-portal) quickly enabled to identify the geocoordinates of all the settlements now in Hungund sub-district, Bagalkot district, Karnataka, except one settlement 'Arasibidi' (Figure 1). Several published records mention the geographical location of this settlement to be at about eight miles $(\sim 10 \mathrm{~km})$ southwest of Aivalli (present-day Aihole) and sixteen miles $(26 \mathrm{~km})$ south of Hungund ${ }^{5,12,23-25}$. A regional map of Bijapur district (of 18 inches: 1-inch scale) has marked Arasibidi south of Gudur ${ }^{5}$. Two 19th century records have slightly different geo-coordinates: $15^{\circ} 54^{\prime}$ and $76^{\circ} 0^{\prime}$ (ref. 12) and, $15^{\circ} 53^{\prime} \mathrm{N}$ and $76^{\circ} 0^{\prime} \mathrm{E}$ (ref. 5); both in Hungund sub-district of the then Bijapur district. When these coordinates were plotted on BHUVAN geo-portal, they appeared in Kushtagi sub-district of the Koppal district and were approximately 18.5 and $20 \mathrm{~km}$ away from Aihole as against $10 \mathrm{~km}$ as mentioned in records, suggesting that both the coordinates were wrong, possibly a printing/computation error (Figure $2 a$ ). Here it is important to state that the Survey of India (SoI) maps published before 2005 followed Everest Datum and Polyconic Projection ${ }^{26}$ and the present geo-portals use WGS-84. These differences, if not

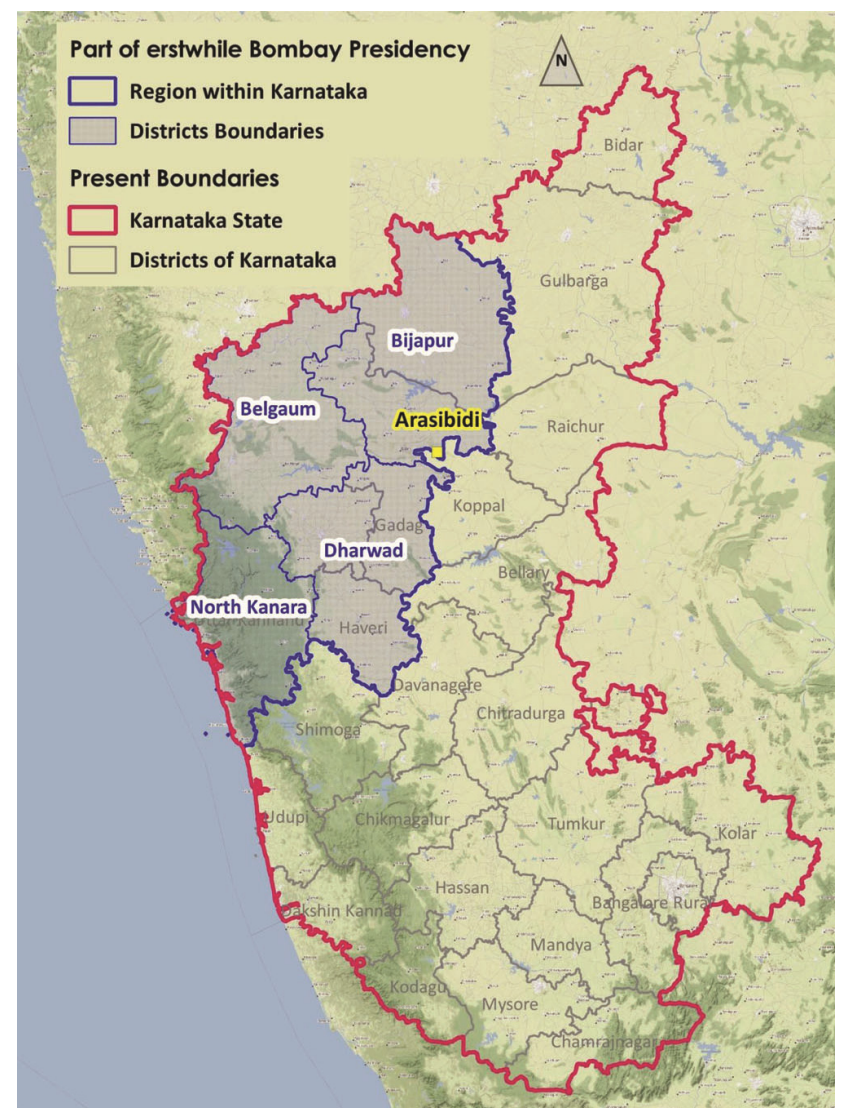

Figure 1. Map of Karnataka with the erstwhile portions of Bombay Presidency marked in blue (Base maps: Stamen Terrain USA/OSM). 

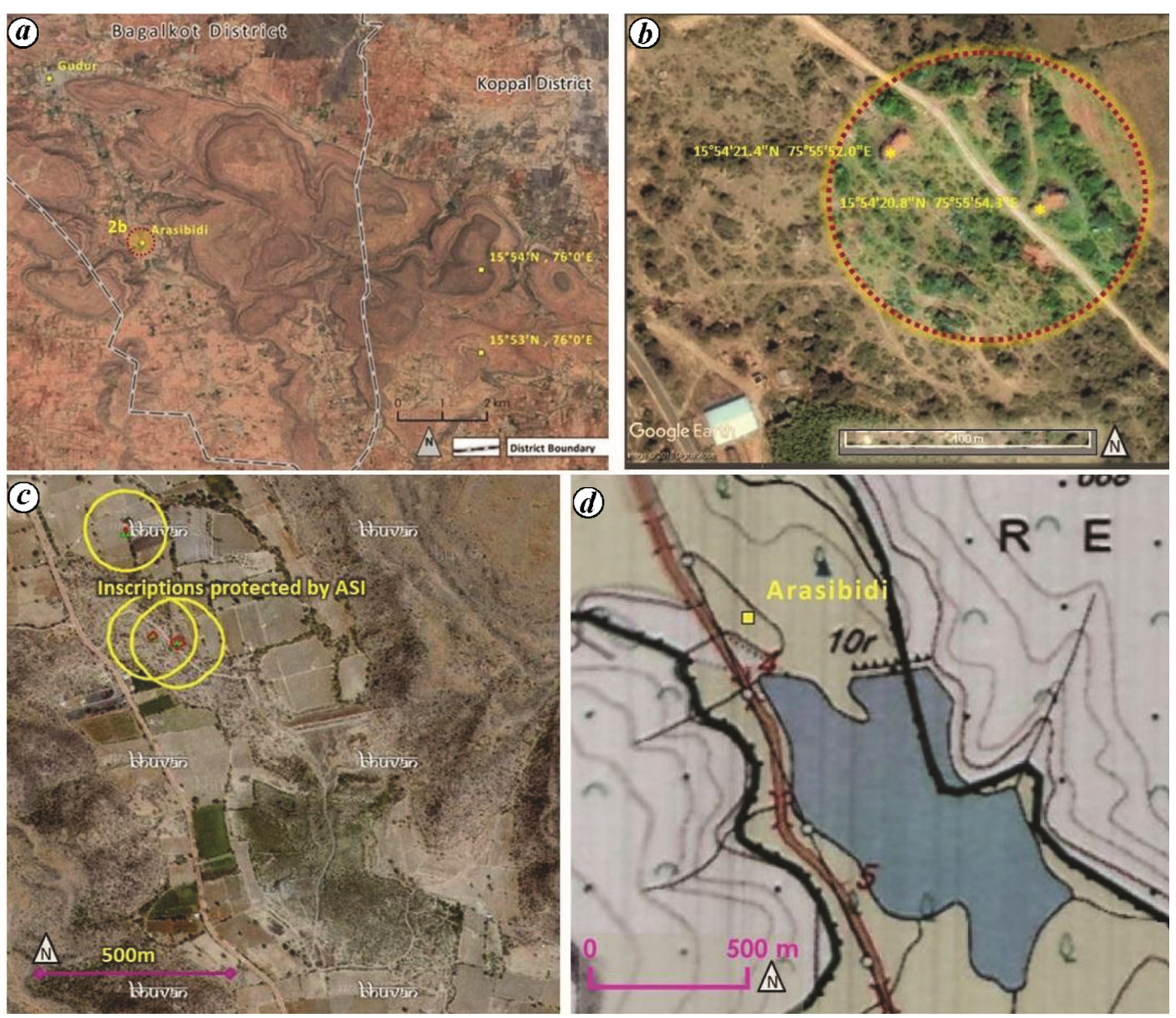

Figure 2. a, Google Earth image showing the district boundaries along with the coarser coordinates marked; $\boldsymbol{b}$, Enhanced Google Earth image of the two temples of Arasibidi, as seen in the typical remote sensing signatures; $c$, BHUVAN image marking the location of the 'three stone bearing inscriptions' as presented in the web page of heritage sites and monuments protected by the ASI; $\boldsymbol{d}$, Survey of India map of 2010 with the absence of any places of worship marked closer to the tank.

re-projected, would induce an error of up to $50 \mathrm{~m}$ (ref. 27). The error of about $10 \mathrm{~km}$ is therefore not because of difference in projection systems. The coarser geocoordinates (absence of arc-second values) added to the complication.

In this scenario of the settlement being displaced into a different sub-district and district, it is important to discuss the changes that occurred in this geographical region at all administration levels (settlement, sub-district, district and state). The Kaladgi district in which Arasibidi was located came under Bijapur district in 1885 (refs 6 and 24) and is currently under Bagalkot district administration since 1997 (ref. 6). Bijapur district was under Bombay Presidency until the formation of Mysore state in 1956 which was christened as Karnataka in 1973. This region also witnessed formation, transfer and merging of sub-districts ${ }^{6,24}$. The records also mention that Arasibidi was in ruins and deserted ${ }^{5,12,23-25}$. When a settlement was found to be deserted/uninhabited/less populated they were merged with the neighbouring settlements for administrative purposes ${ }^{6,28}$ and no longer discussed in government reports and records as an individual settlement. Hence, gazetteers, antiquarian report and old maps published under the Kaladgi, Bijapur and Bagalkot district of Bombay Presidency, Mysore state and Karnataka had to be scrutinized for Arasibidi's geographical description and location. Arasibidi, the Chalukyan capital, is spelt as Arasibeedi in 2006 Gazetteer and according to all the records it was located in Hungund sub-district. In addition, while screening all the settlements listed under Hungund sub-district of 1877 report, it was found that they are all within the administration of the present Bagalkot district. Therefore, it is possible that Arasibidi/ Arsibeedi also would be located in Hungund sub-district of Bagalkot district rather than being displaced into Kushtagi sub-district as it appeared when plotted using the above mentioned coarser coordinates. The identification of multiple spellings of the same place name and recording them appropriately as attributes in the same vector layer are important in geospatial documentation because most information connected to the settlement and its monuments (as provided in the historical records) 


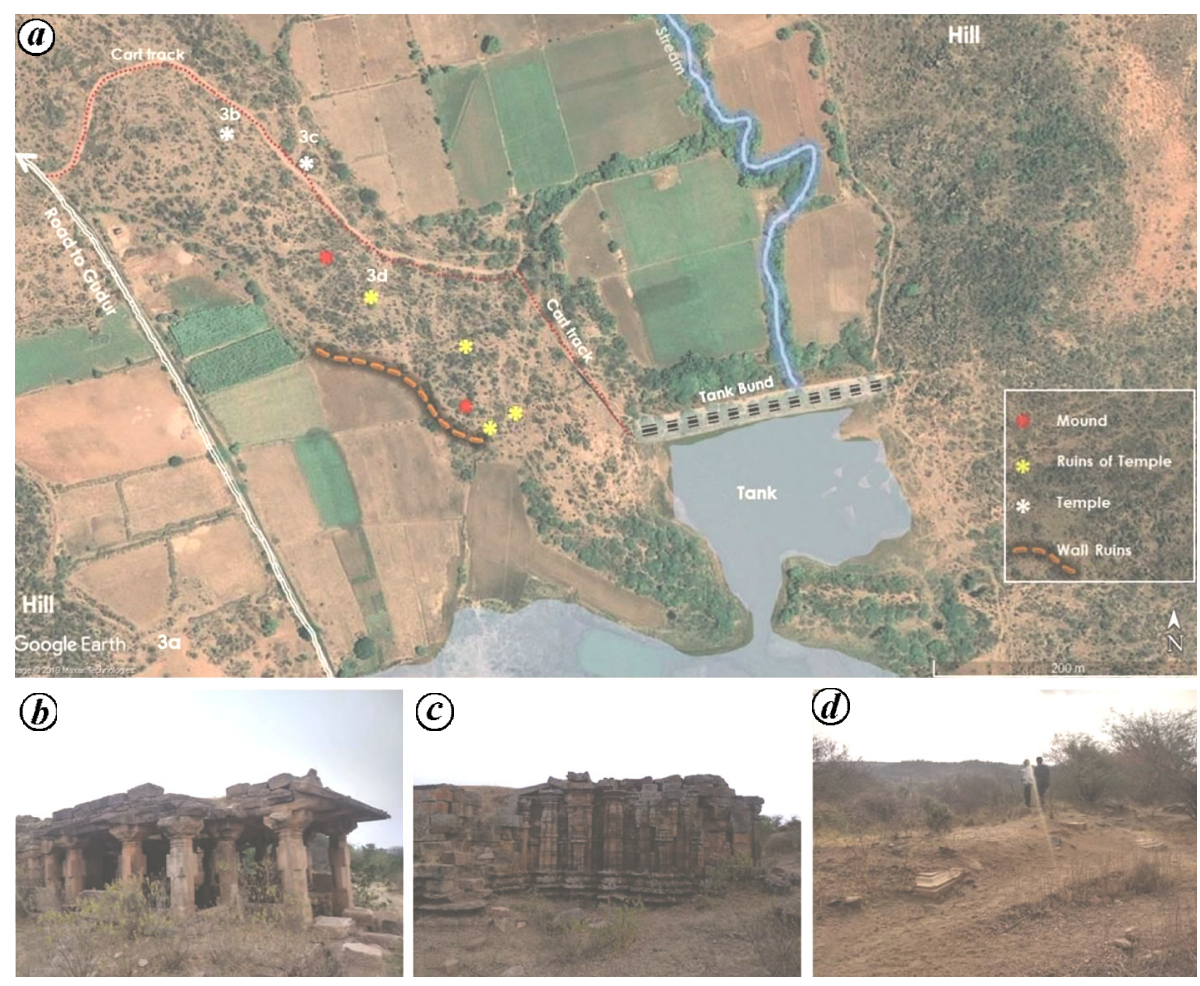

Figure 3. $\boldsymbol{a}$, Google Earth image with the locations of the temples and ruins marked. $\boldsymbol{b}$, Temple in ruins to the west at Arasibidi. $\boldsymbol{c}$, Temple in ruins to the east at Arasibidi. $\boldsymbol{d}$, Ruins of a temple at Arasibidi.

would be referred by the place name. The layer with place name plays a vital role in supporting user interaction with databases created using geographic information technology ${ }^{7}$.

Since Arasibidi was one of the capitals and also was listed in the 1877 antiquarian remains report, there is a high chance of the monuments of Arasibidi being protected by either Central or State Archaeology. But the name Arasibidi was not conspicuous in the ASI's list of protected monuments. The list of protected monuments by ASI is categorized first by their administrative levels as State, Circle, Sub-circle and District, and second by the type of 'monument' (for example Buddhist stupa sites, forts, inscriptions, mosques, pre-historic sites, rockcut caves, temples, basadis and tombs). By carefully scrutinizing each of the lists under Bagalkot district (ASI, Dharwad Circle, Karnataka) one can find three 'stones bearing inscriptions' at a location 'Arshibidi (Gudur)' (yet another spelling). These have serial number 102, 103 and 104 in the websites of ASI, New Delhi ${ }^{16}$ and Press Information Bureau ${ }^{29}$, but with a different sequence of numbering $(61,62,63)$ on the website of Dharwad cir$\mathrm{cle}^{30}$. BHUVAN - ASI 'All India inventory of sites and monuments' web portal (BASI) where all the centrally protected ASI sites are geo-tagged, does not list monuments based on the name of the settlement/monument/ location but only with the name of the monument category. This does not allow the search on a database with the name of the monument nor does it use the place names Arasibidi/Arasibeedi/Arshibidi (even if varied spellings are queried). Further, the recent website of Dharwad circle provides photographs of each of the three inscriptions and gives an embedded google map marking the location. But on the webpage of all the three above mentioned inscriptions $^{31}$, the embedded map marks the location of Gudur $^{32}$, which would have obviously been generated using 'machine-learned classifiers' discussed earlier. The list of monuments protected by $\mathrm{DAMH}^{33}$ (with no geocoordinates mentioned) identifies Arshibidi of Hungund sub-district as a location but does not list any protected monument at this location. If the structure of the digital database is designed to enable search and query not only in the organization hierarchy of ASI but also through associated metadata, one could have found this site more easily. From the above mentioned reasons of (a) different spelling of the settlements, (b) coarser coordinates, (c) merger and transfer of taluk, district and state boundaries, (d) absence of geo-coordinates in the archaeology department's listing and (e) absence of monument name in the geo-portal-it was important to ascertain, the existence and precise location of Arasibidi geospatially and through ground validation.

Since this village was marked to the south-east of Gudur in Bijapur district maps of 1884 (ref. 5) a scrutiny of open series maps of $\mathrm{SoI}^{34,35}$ was undertaken to look for locations marked as 'uninhabited settlement' or a 
'monument' or 'a place of worship' using the reference of Gudur and the tank (as mentioned in antiquarian report), but this effort was in vein (Figure $2 d$ ). SoI maps record all the built forms (monuments, places of worship and water features) and topographic features, but the absence of this settlement name can be attributed to merger and transfer of administrative boundaries, which might have led to its removal from these maps. Examining the cadastral/revenue maps of the nearby settlements of Gudur and Muradi was also futile ${ }^{36}$. The web portal BASI when verified again along the Gudur-Hanamsagar road (the only road to the south of Gudur) and at about $4 \mathrm{~km}$ from Gudur as mentioned by Kokatanur (Arasibidi is locally called Arasibuddi according to Kokatanur) ${ }^{37}$ does mark three protected sites closer to a tank as 'stone bearing inscriptions' but does not mention a place name (Figure $2 c$ ). A closer look at two of these protected sites on other geoportals BHUVAN (2D) and Google Earth shows two features that are typical remote sensing signatures for temples (Figure $2 b$ ).

The coordinate location identified through geo-spatial analysis was reached by GPS navigation and local enquiry. Ground validation at this above-identified location enabled in spotting all the following features mentioned in published literature: (1) two ruinous temples and a mound (with the remains of at least two other temples, and few other structures) (Figure 3) as mentioned in antiquarian remains report ${ }^{22}$, (2) Arasibidi having a tank called 'Sindaragere' in an inscription from AD 1075 (ref. 38), (3) remains of fort wall as described by Cousens ${ }^{39}$, and (4) structures resembling the photos published by Siddeshwar $^{40}$ and Krishnan ${ }^{41}$ and as per the description of temples by Kokatanur ${ }^{37}$. Though it is a protected site there was no signage at the location which describes the protection status and importance of the site, as generally found in most of the ASI protected sites. Finding all these four features collectively assured that this location is Arasibidi. Through the correlation of old maps, images and records published about the settlement, the geo-coordinates at one of the temples were recorded as $15^{\circ} 54^{\prime} 21.4^{\prime \prime} \mathrm{N}$ and $75^{\circ} 55^{\prime} 52.0^{\prime \prime} \mathrm{E}$. However, the question of why SOI maps have not marked the two temples still remains open.

\section{Conclusion}

Geotagging lesser-known and unprotected monuments/ sites in India is challenging and this is not a direct task where information can be collected from SoI maps or web-mapping portals like BHUVAN or Google Earth, but has to be cautiously carried out using various literature and ground validation. The example discussed above is not an archaeological mound but a nationally protected site with historical remains in ruinous condition frequently mentioned in the literature. Many such lesser-known her- itage sites are not protected by law eventually leading to the complete loss of property. Gupta et al. ${ }^{20}$ discuss the need for bringing built-heritage data into a single geospatial platform, which includes all the sites (whether protected by centre or state or unprotected). Such documentation becomes vital especially in the context of those sites which were un-inhabited since a long time (few examples are Talvarkop of Belgaum district, Akkargal of Bagalkot district, Bhavihal of Dharwad district).

Protecting and safeguarding culture and natural heritage $^{42}$ is one of the goals of the United Nations for a global sustainable development - which stems from its main philosophy that "no development can be sustainable without strong cultural component ${ }^{43}$. Feilden ${ }^{44}$, a renowned conservation architect who has worked with heritage buildings across the world, says built heritage which is a fragment of the culture of a place adds to 'the values of continuity and identity for the inhabitants'. The Indian National Trust for Art and Cultural Heritage (INTACH) ${ }^{45}$ has guidelines for listing out the unprotected architectural heritage sites of India based on sites' historical significance, integrity and context through background research and fieldwork. With the vast number of unprotected heritage sites of India, this traditional method by fieldwork could be time consuming and laborious. Thus as mentioned by Indian Heritage in Digital Space Research ${ }^{46}$, bringing India's unprotected monuments into a geospatial platform would still be a monumental task considering the number of undocumented heritage remains in India. However, the systematic method of geospatial documentation of sites by bringing in information from various sources demonstrated in this article would still be a workable means of covering a large number of sites in a less laborious and less time-consuming way and making it accessible in the public domain to create awareness about the importance and historicity of the place would be a practical way forward.

1. Ancient Monuments and Archaeological Sites and Remains Rules 1959, Ministry of Scientific Research and Cultural Affairs, Government of India, New Delhi, 1959.

2. www.thehindu.com/news/national/karnataka/34229-temples-to-getgrant-of-Rs.-36000-every-year/article13978082.ece (accessed on 26 August 2019).

3. DeLozier, G., Baldridge, J. and London, L., GazetteerIndependent toponym resolution using geographic word profiles. In Proceedings of the Twenty-Ninth AAAI Conference on Artificial Intelligence, 2015, pp. 2382-2388.

4. Beyan, O., An Overview of Geotagging, Royal Irish Academy, Dublin, 2016.

5. Campbell, J. M., Gazetteer of the Bombay Presidency Volume XXIII Bijapur, Government Central Press, Bombay, 1884.

6. Jeelani, S., Gazetteer of India, Karnataka State Gazetteer, Bijapur District (Bagalkot District included), Government of Karnataka, Bangalore, 2006.

7. Goodchild, M. F. and Hill, L. L., Introduction to digital gazetteer research. Int. J. Geogr. Inf., 2008, 22(10), 1039-1044.

8. Mitra, S., Grover, A. \& Singh, R., Handbook of Conservation of Heritage Buildings - A Guide, Central Public Works Department, New Delhi, 2013. 
9. Thakurta, T. G., Monuments, Objects, Histories, Columbia University Press, New York, 2004.

10. Cunningham, A., Four Reports Made during the Year 1862-63, 64, 65, Archaeological Survey of India, Simla, 1871.

11. Roy, S., Indian archaeology from Jones to Marshall (1784-1902). Ancient India Bull. Archaeol. Surv. India, 1953, 9, 4-28.

12. Burgess, J., List of the Antiquarian Remains in the Bombay Presidency, Archaeological Survey of Western India, Bombay, 1885.

13. GoI, The Ancient Monuments Preservation Act No. VII of 1904(as modified up to 1 September 1949), Gazette of India, New Delhi, 1949; https://asihyderabadcircle.com//storage/files/C6Z7AV46pJL9n4mLBaLj8eOQ6ZVF69uzyxJiSnDo.pdf (accessed on $26 \mathrm{Au}$ gust 2019).

14. GoI, The Ancient and Historical Monument and Archaeological Sites and Remains (Declaration of National Importance) Act, 1951 (Act no LXXI), Government of India, New Delhi, 1951; www.asichennai.gov.in/downloads/ahmasr_act 1951.pdf (accessed on 26 August 2019).

15. Mathrani, R. and Sharma, S. K., Report on Performance Audit of Preservation and Conservation of Monuments and Antiquities, Union Government (Civil) Ministry of Culture, New Delhi, 2012.

16. Archaeological Survey of India; www.asi.nic.in/alphabetical-list-ofmonuments-karnataka-dharwad/(accessed on 28 July 2019).

17. Department of Kannada and Culture; www.kannadasiri.kar.nic.in/ archaeology/eng/e_contents.htm (retrieved on 26 August 2019).

18. https://bhuvan-app1.nrsc.gov.in/culture monuments/ (accessed on 26 August 2019)

19. INTACH, Charter for Conservation of Unprotected Architectural Heritage and Sites in India, Indian National Trust for Art and Cultural Heritage, New Delhi, 2004.

20. Gupta, E. et al., The need for an Archaeological database. Curr. Sci., 2017, 113(10), 1961-1973.

21. Gregory, I., A Place in History: A Guide to Using GIS in Historical Research (AHDS Guides to Good Practice), The Arts and Humanities Data Service and Oxbow Books, Oxford, 2005.

22. Fleet, J. F. and Burgess, J., Revised list of remains in the Ahmad Nagar, Nasik, Puna, Thana, and Kaladgi Zillas. In Antiquities of the Talukas of Parner, Sangamner, Ankola, and Kopargaum (ed. Sinclair, W. F.), Archaeological Survey of Western India, Calcutta, 1877, pp. 12-27.

23. Cousens, H., Revised List of the Antiquarian Remains in the Bombay Presidency, Archaeological Survey of India, Bombay, 1897.

24. Enthoven, R. E. and Edwardes, S. M., Imperial Gazetteer of India Provincial Series, Volume II, Superintendent of Government Printing, Calcutta, 1909.

25. Sathyan, B. N., Mysore State Gazetteer Bijapur District, Government Press, Bangalore, 1966.

26. Survey of India; www.surveyofindia.gov.in/pages/display/246publications (accessed on 17 December 2019).

27. Srivastava, B. K. and Ramalingam, K., Error Estimates for WGS84 and Everest (India - 1956) Transformation. Geospatial World, 2009; www.geospatialworld.net/article/error-estimates-for-wgs-84and-everest-india-1956-transformation/ (accessed on 17 December 2019).

28. Census of India; www.censusindia.gov.in/2011census/A-3 V Vill/ Note_A-3_Villages_Population.pdf (accessed on 26 August 2019).
29. Press Information Bureau; www.pib.nic.in/newsite/erelcontent. aspx?relid=76471 (accessed on 28 July 2019).

30. Archaeological Survey of India Dharwad Circle; www. asidharwadcircle.in/wp-content/uploads/2019/04/List-of-Monuments. pdf (accessed on 26 August 2019).

31. Archaeological Survey of India Dharwad Circle; www. asidharwadcircle.in/monuments/?search keywords=\&search region $=97 \&$ search categories $\% 5 \mathrm{~B} \% 5 \mathrm{D}=$ (accessed on 12 August 2019).

32. Archaeological Survey of India Dharwad Circle; www. asidharwadcircle.in/monument/stone-bearing-an-inscription/ (accessed on 12 August 2019).

33. Department of Kannada and Culture; www.kannadasiri. kar.nic.in/archaeology/eng/E08 Bagalkote.htm (retrieved on $26 \mathrm{Au}$ gust 2019).

34. SoI, Karnataka Map of grid 48M13, Scale 1:50,000, Survey of India, Government of India, 1976, 1st edn.

35. SoI, Open Series Map D43D13, Scale 1:50,000, Survey of India, Government of India, Bangalore, 2010.

36. www.landrecords.karnataka.gov.in/service3/ (retrieved on 17 December 2019).

37. Kokatanur, S. P., Arasibidi: a forgotten capital of Chalukyas. Zenith Int. J. Multidisci. Res., 2019, 9(1), 207-213.

38. Desai, P., Sircar, D. C. and Gai, G., South Indian Inscriptions Volume XV: Bombay Karnataka Inscriptions: Volume II, The Manager of Publications, Madras, Delhi, 1964.

39. Cousens, H., The Chalukyan Architecture of the Kanarese District, Government of India Cental Publication Branch, Calcutta, 1926.

40. www.karnatakatravel.blogspot.com/2013/04/arshibidutemples.html (accessed on 9 June 2018).

41. www.deccanherald.com/spectrum/spectrum-statescan/mappinglifelines-a-step-towards-their-revival-748186.html (accessed on 22 July 2019).

42. https://sustainabledevelopment.un.org/sdg11 (accessed on $22 \mathrm{Au}$ gust 2019).

43. https://en.unesco.org/themes/protecting-our-heritage-andfostering-creativity (accessed on 22 August 2019).

44. Feilden, B., Guidelines for Conservation A Technical Manual, The Indian National Trust for Art and Cultural Heritage, New Delhi, 1989.

45. INTACH, www.intach.org/about-charter-guidelines.php\#b2 (accessed on 2 July 2019).

46. Department of Science and Technology; www.dst.gov.in/indianheritage-digital-space-research (accessed on 19 April 2019).

ACKNOWLEDGEMENTS. I thank my PhD supervisor Dr M. B. Rajani for guidance; the National Institute of Advanced Studies, Bangalore for institutional support; the 'Indian Heritage in Digital Space' scheme of Department of Science and Technology for financial support.

Received 1 November 2019; revised accepted 3 January 2020

doi: $10.18520 / \mathrm{cs} / \mathrm{v} 118 / \mathrm{i} 6 / 877-882$ 